\title{
Kepemimpinan Kepala Sekolah dan Profesionalisme Guru Bahasa Arab Pesantren di Kota Lhokseumawe
}

\author{
Aina Salsabila \\ IAIN Lhokseumawe \\ ainasalsabila89@gmail.com
}

\begin{abstract}
In a number of junior high schools based on the Islamic boarding school in Lhokseumawe city do not have Arabic teachers with educational backgrounds according to their fields of expertise, this will affect the professionalism of teachers in teaching Arabic subjects. The purpose of this study was to explain the leadership style of principal's Junior High School (MTSS) in carrying out their duties, to descripe the professionalism of Arabic Junior high School (MTSS) teachers in carrying out their duties and to know the influence of principal leadership style on the professionalism of Arabic Junior High School teachers in Islamic boarding school in Lhokseumawe City. The method used is a survey method with a quantitative approach, the sample is 27 respondents. Data analyzes using simple linear regression. The results showed that $81 \%$ (22 teachers) favored the principal's leadership style and 70\% (19 Arabic language teachers) were able to develop their professional competencies. Simple linear regression test results show the significance value for the influence of $X$ on $Y$ is 9,308>2,055, thus there is a significant influence of school leadership on the professionalism of Arabic MTsS Islamic boarding School teachers in Lhokseumawe, then $\mathrm{H}_{0}$ is rejected and $\mathrm{Ha}$ is accepted. From the data analysis it was found that the performance of the MTsS Islamic Boarding School principals in Lhokseumawe was already good, the majority of school principals understood their managerial duties in managing schools and directing Arabic language teachers to improve their competence, but the level of teachers professionalism was not it is only influenced by external factors (principal's leadership) but is also greatly influenced by internal factors such as self-motivation and teacher competencies.
\end{abstract}

Keywords: Principal's Leadership, Profesionalism, Teacher

\begin{abstract}
Abstrak
Pada beberapa Madrasah Tsanawiyah yang berbasis pesantren di kota Lhokseumawe belum memiliki guru bahasa Arab yang berlatar belakang pendidikan sesuai bidang keahliannya, hal ini akan berpengaruh pada keprofesionalisme guru dalam mengajarkan mata pelajaran bahasa arab. Tujuan penelitian ini untuk mengetahui gambaran gaya kepemimpinan kepala sekolah MTsS dalam melaksanakan tugasnya, gambaran profesionalisme guru bahasa Arab MTsS dalam melaksanakan tugasnya dan pengaruh gaya kepemimpinan kepala sekolah MTsS terhadap profesionalisme guru bahasa Arab MTs Pesantren di Kota Lhokseumawe. Metode yang digunakan adalah metode survei dengan pendekatan kuantitatif dan jumlah sampel sebanyak 27 responden. Analisis data menggunakan regresi linear sederhana. Hasil penelitian menunjukkan bahwa 81\% (22 guru) menyenangi gaya kepemimpinan kepala sekolah dan 70\% (19 guru bahasa arab) telah mampu mengembangkan kompetensi yang
\end{abstract}


dimiliki secaraprofesional. Hasil uji regresi linear sederhana menunjukkan nilai signifikansi untuk pengaruh $X$ terhadap $Y$ adalah sebesar 9,308 > 2,055, dengan demikian terdapat pengaruh yang signifikan kepemimpinan kepala sekolah terhadap profesionalisme guru Bahasa Arab MTsS Pesantren di Lhokseumawe,maka Ho ditolak dan $\mathrm{Ha}_{a}$ diterima.Dari analisis data ditemukan bahwa kinerja kepala sekolah MTsS Pesantren di Lhokseumawe sudah baik, mayoritas kepala sekolah sudah memahami tugas manajerialnya dalam mengelola sekolah dan mengarahkan guru bahasa Arab agar dapat meningkatkan kompetensi yang dimilikinya, namun tingkat profesionalisme guru bahasa Arab tidak hanya dipengaruhi oleh faktor eksternal saja (kepemimpinan kepala sekolah) tetapi juga sangat dipengaruhi oleh faktor internal seperti motivasi diri dan kompetensi guru.

Kata Kunci; Kepemimpinan Kepala Sekolah, Profesionalisme, Guru

\section{A. PENDAHULUAN}

Dalam dunia pendidikan kepala sekolahmempunyai peranan penting demi terciptanya efektivitas dan efisiensi pendidikan. Untuk kemajuan mutu pendidikan khususnya guru dibutuhkan kinerja kepala sekolah yang optimal. Hal ini dapat terealisasi dengan meningkatkan kinerja kepala sekolah dalam menjalankan fungsi kepemimpinan manajerial dan memperbaiki efektivitas sekolah melalui peningkatan pemahaman dan penguasaan terkait kompetensi kepemimpinan dan manajerial. Kepala sekolah memiliki kemampuan merencanakan, mengorganisasikan, mengkomunikasikan, memotivasi bawahan, mengarahkan, dan pengawasan (pengendalian) terhadap kegiatan sekolah.

Sebagaimana yang diungkapkan oleh Satori J : Keberhasilan atau kegagalan suatu sekolah dalam menampilkan kinerjanya secara memuaskan banyak tergantung pada kualitas kepemimpinan kepala sekolahnya yang ditunjukkan oleh iklim kehidupan sekolah, budaya organisasi sekolah, etos kerja, semangat kerja guru, prestasi belajar siswa, disiplin warga sekolah secara menyeluruh [Riduwan, 2015, 325].

Dalam Peraturan Menteri Pendidikan Nasional Nomor 13 Tahun 2007 tentang Standar Kepala Sekolah/Madrasah terdapat 5 (lima) dimensi kompetensi yang harus tertanam dalam pribadi kepala sekolah agar menjadi pemimpin yang efektif, yaitu: kepribadian, manajerial, 
kewirausahaan, supervisi, dan sosial. Pada kerangka Manajemen Berbasis Sekolah (MBS), kepala sekolah bertanggungjawab atas pelaksanaan manajemen sekolah, pembelajaran aktif, interaktif, kreatif, efektif, dan menyenangkan (PAIKEM) serta partisipasi masyarakat dalam mendukung program sekolah.

Peran kepala sekolah sebagai pemimpin dan manajerial dapat mewujudkan sekolah yang efektif, sehingga kedudukan kepala sekolah hanya dapat di duduki oleh pribadi yang kompeten. Kepala sekolah harus memenuhi kompetensi minimal diantaranya tindakan dalam mengarahkan dan mengkoordinasikan kerja anggota kelompok [Mulyadi: 2010, 47]. Sebagai pemimpin, peran kepala sekolah sangat penting dalam memberi arahan dan motivasi bagai peningkatan kualitas para guru. Pola ini akan terbentuk, jika kepala sekolah harus merubah pola pikir, sikap, tingkah laku yang dipimpinnya. Sehingga dengan kualitas diri, pengetahuan dan pengalaman akan mampu meningkatkan tingkat profesional guru.

Perilaku kepemimpinan menurut Wahjosumidjo [1987, 61-62] mengemukakan bahwa konsiderasi adalah dominasi perilaku pemimpin pada kepentingan bawahan. Adapun ciri-ciri perilaku pemimpin, yaitu: (a) ramah tamah, (b) mendukung dan membela bawahan, (c) mau mendengar bawahan, (d) menerima usul bawahan, (e) memikirkan kesejahteraan bawahan, (f) memperlakukan bawahan setingkat dirinya. sedangkan struktur inisisasi adalah perilaku pemimpin lebih mendahulukan tujuan organisasi. Oleh karena itu perilaku pemimpin mempunyai ciri-ciri: (a) adanya kritik terhadap kinerja yang tidak baik, (b) adanya batasan waktu pelaksanaan tugas bagi bawahan, (c) adanya daftar pekerjaan yang harus dikerjakan oleh bawahan (d) adanya petunjuk kerja bagi bawahan dalam melaksanakan tugas, (e) standarisasi pekerjaan, (f) mengarahkan bawahan berkerja sesuai standar yang ditetapkan, (g) pengawasan dan evaluasi terhadap 
kinerja bawahan sesuai selalu mengawasi apakah bawahan bekerja sepenuh kemampuan.

Sutarto [2011, 83] menyatakan bahwa perilaku kepemimpinan dibagi dua yaitu: "initiating structure" (struktur tugas) dan "consideration" (tenggang rasa). Perilaku kepemimpinan "initiating structure" (struktur tugas) memiliki ciri-ciri sebagai berikut: (a) mengutamakan tercapainya tujuan, (b) mementingkan produksi yang tinggi, (c) mengutamakan penyelesaian tugas menurut jadwal yang telah ditetapkan, (d) lebih banyak melakukan pengarahan, (e) melaksanakan tugas dengan melalui prosedur kerja yang ketat, (f) melakukan pengawasan secara ketat, (g) penilaian terhadap pejabat semata-mata berdasarkan hasil kerja, sedangkan perilaku kepemimpinan "consideration" tenggang rasa mengandung ciri-ciri: (a) memperhatikan kebutuhan karyawan, (b) berusaha menciptakan suasana saling percaya, (c) berusaha menciptakan suasana saling menghargai, (d) memiliki sikap bersahabat, (e) menumbuhkan peranserta dalam pembuatan keputusan dan kegiatan lain, (f) lebih mengutamakan pengarahan diri, mendisiplinkan diri, dan mengontrol diri. Dari uraian di atas dapat disintesakan bahwa kepala sekolah sebagai manajer, administrator, supervisor, manajer berada pada ruang lingkup kepala sekolah sebagai manajer, dan educator, inovator dan leader berada pada ruang lingkup kepala sekolah sebagai pemimpin.

Begitu besar peran dan otoritas kepala sekolah dalam melaksanakan tugas dan fungsi jabatannya terhadap lembaga sekolah yang dipimpinnya. Oleh karena itu pelaksanaan pelatihan, seminar, workshop dan kegiatan lainnya untuk meningkatkan pemahaman dan kompetensi kepala sekolah dalam kepemimpinan sering diadakan oleh lembaga pemerintahan. Dalam menjalankan tugasnya kepala sekolah selalu akan berinteraksi dengan guru dan siswa dibawah kewenangannya di sekolah, baik dalam hal manajerial, 
pengorganisasian, kurikulum, kesiswaan dan lain sebagainya akan selalu ada ikut campur kepala sekolah sebagai pemimpin. Bagaimanakah cara kepala sekolah akan membawa sekolahnya menjadi sekolah yang bergengsi dengan sumber daya yang sangat unggul, ini akan selalu menjadi PR bagi kepala sekolah. Di antara sumber daya yang unggul itu pastinya akan memiliki siswa yang unggul pula, untuk menciptakannya diperlukan kepala sekolah yang bisa menciptakan tenaga kependidikan yang unggul dan profesional.

Peran guru yang profesional diperlukan sekali untuk mewujudkan tujuan pendidikan nasional, yakni mencerdaskan kehidupan bangsa dan mengembangkan manusia seutuhnya, sesuai dengan UU RI No. 20 Tahun 2003 tentang Sistem Pendidikan Nasional, bahwa jabatan guru sebagai pendidik merupakan jabatan profesional. Untuk mampu bersaing di forum nasional maupun internasional, profesionalisme guru dituntut untuk terus berkembang sesuai dengan perkembangan jaman, ilmu pengetahuan dan teknologi. Untuk menjadi guru profesional harus memiliki beberapa kompetensi. Dalam undang-undang Guru dan Dosen No.14/2005 Bab IV pasal 10 ayat 1 dan Peraturan Pemerintah No.19/2005 tentang Standar Nasional Pendidikan Bab VI pasal 28 ayat 3 dinyatakan bahwa kompetensi guru meliputi kompetensi pedagogik, kompetensi kepribadian, kompetensi sosial dan kompetensi profesional.

Guru wajib mengembangkan dan memanfaatkan kemampuan profesionalnya, sehingga dapat meningkatkan kinerja dalam melaksanakan tugas dan fungsionalnya. Dengan berkembangnya ilmu pengetahuan dan teknologi maka guru harus mampu membawa siswa atau peserta didik untuk memasuki dunia ilmu pengetahuan dan teknologi yang terus menerus berkembang. 
Muhibbin Syah $(1999,229)$ menyatakan bahwa "Guru yang berkualitas adalah guru yang berkompetensi, yang berkemampuan untuk melaksanakan kewajiban-kewajibannya secara bertanggungjawab dan layak". Sedangkan Ani M. Hasanmenjelaskan bahwa guru yang profesional harus memenuhi beberapa kriteria, antara lain: (1) mempunyai komitmen terhadap siswa dan proses belajarnya, (2) menguasai secara mendalam bahan/mata pelajaran yang diajarkannya serta cara mengajarnya kepada siswa, (3) bertanggungjawab memantau hasil belajar siswa melalui berbagai cara evaluasi, (4) mampu berpikir sistematis tentang apa yang dilakukannya dan belajar dari lingkungan profesinya.

Salah satu faktor penyebab rendahnya kemampuan guru dalam memahami mata pelajaran adalah masih rendahnya tingkat kualifikasi guru pada setiap jenjang pendidikan. Berkaitan dengan hal itu Jalal dan Supriadi (2001, 262) mengemukakan bahwa: “Dalam kenyataannya, mutu guru amat beragam. Berbagai penelitian mengungkapkan bahwa tingkat penguasaan bahan ajar dan ketrampilan dalam menggunakan metode mengajar yang inovatif masih kurang.

Dalam penjabaran keempat kompetensi yang harus dimiliki oleh seorang guru masing-masing memiliki peranan yang sangat dominan dalam kacamata siswa karena ada kalanya seorang guru tidak memiliki keempat kompetensi tersebut secara maksimal. Ada guru yang sangat mampu di bidang pedagogik namun kurang dalam hal kepribadian, ada guru yang sangat mampu berkomunikasi dengan baik dan interaksi sosial masyarakat sangat bagus akan tetapi kurang dalam kompetensi profesionalnya. Oleh karena itu, seyogyanya seorang guru harus bisa memiliki keempat kompetensi ini secara maksimal agar semua yang dilakukan untuk siswanya juga maksimal.

Profesi merupakan pekerjaan, dapat pula berwujud sebagai jabatan di dalam suatu hierarki organisasi birokrasi, yang menuntut 
keahlian tertentu serta memiliki etika khusus untuk jabatan tersebut serta pelayanan baku terhadap masyarakat. Dengan demikian profesional adalah orang-orang yang melaksanakan tugas profesi, melaksanakan tugas secara profesional yang dituntut adanya keahlian, tanggung jawab, dan kesetiaan terhadap profesi yang diperolehnya melalui pendidikan dan pelatihan. Salah satu peranan guru adalah "transfer of knowlwdge" dan "tranferof values". Jadi guru adalah seorang yang profesinya bertugas mengajar atau mendidik anak dan itu merupakan salah satu pekerjaan mata pencaharianya yang patut ditiru/dicontoh.

Fenomena saat ini di beberapa sekolah masih terdapat guru yang belum memiliki keahlian dan kompetensi yang sesuai dengan mata pelajaran yang diajarkannya. Hal ini ditemukan pada beberapa Madrasah Tsanawiyah yang berbasis pesantren di kota Lhokseumawe, dimana saat ini belum memiliki guru bahasa Arab yang berlatar belakang pendidikan sesuai bidang tugasnya. Fakta yang ditemukan di Madrasah Tsanawiyah yang berbasis pesantren bahwa mayoritas guru yang mengajar bahasa arab adalah alumni pesantren yang pernah belajar bahasa arabdengan latar belakang pendidikannya berbeda, seperti lulusan dari dari bidang ilmu Bahasa Inggris, Matematika, Biologi, Kimia, Syari'ah, Ekonomi, Ushuluddin dan Dakwah. Sehingga pemahaman atau keprofesionalisan akan mata pelajaran yang diajarkan kepada anak didik tidak terpenuhi dengan baik. Idealnya penting bagi guru memahami kompetensi yang harus dimiliki oleh seorang guruterutama dalam menyiapkan perangkat pembelajaran, memahami dan menyususn materi, serta memiliki keterampilan dan pengetahuan tentang keguruan yang maksimal.

Berdasarkan permasalahan di atas terungkap bahwa rendahnya profesionalisme guru tidak hanya dipengaruhi oleh faktor internal guru saja tetapi juga oleh faktor eksternal termasuk peran dan kebijakan 
kepemimpinan kepala sekolah yang kurang maksimaldalam meningkatkan mutu pendidikan. Profesionalisme guru khususnya guru bahasa Arab di sekolah MTsS yang berlatar pesantren di kota Lhokseumawe diharapkan dapat terwujud melalui bantuan dan bimbingan kepala sekolah agar hasil belajar bahasa Arab lebih maksimal.

St. Kuraidah dalam jurnalnya berjudul "Kinerja Supervisor dan Profesionalisme Guru Bahasa Arab Madrasah Aliyah di Kota Kendari" menyatakan bahwa upaya awal yang dilakukan dalam perbaikan mutu pendidikan adalah kualitas guru, untuk mewujudkannya memerlukan bantuan supervisor.Tujuan penelitiannya untuk mengetahui secara umum kinerja supervisor dalam melaksanakan tugas kepengawasan, untuk mengetahui profesionalisme guru bahasa Arab, dan pengaruh kinerja supervisor terhadap profesionalisme guru bahasa Arab pada Madrasah Aliyah di kota Kendari.Hasil penelitian menunjukkan bahwa: 1) Secara umum kinerja supervisor dalam melaksanakan tugas kepengawasan pada Madrasah Aliyah berada pada kategori baik sekitar 88\%, dan selebihnya dalam kategori cukup. 2) Profesionalisme Guru bahasa Arab di Madrasah Aliyah Kota Kendari, berada pada kategorisangat baik $48 \%$, kategori baik $44 \%$ dan cukup $2 \%$ masih berada pada kategori cukup. 3). Sekalipun semua berada pada kategori baik tetapi dari hasil uji analisis statistik ditemukan tidak terdapat pengaruh positif dan signifikan kinerja supervisor terhadap profesionalisme guru [ St. Kuraidah, Jurnal Al-Izzah, Vol. 8 No. 2 Desember 2013, 104]

Kemudian Miswari juga dalam jurnalnya menuliskan tentang "Peningkatan Profesionalisme Guru Bahasa Arab: Upaya Peningkatan Mutu Pembelajaran Bahasa Arab" menyimpulkan bahwa semua orang yang berprofesi sebagai guru, termasuk guru bahasa Arab harus memiliki seperangkat kemampuan minimal atau kompetensi, baik 
kompetensi paedagogik, profesional, personal maupun sosial. Hanya dengan empat hal inilah guru bahasa Arab dapat menjalankan tugasnya secara efektif dan efisien [Miswari, Jurnal Ta'dib, Vol. XV. No. 02. Edisi, Nopember 2010, 255].

Adapun penelitian ini lebih spesifik berlandaskan kepada pengaruh gaya kepemimpinan kepala sekolah terhadap profesionalisme guru bahasa Arab yang berada di sekolah MTsS pesantren di Kota Lhokseumawe.

\section{B. Metode}

Metode yang digunakan dalam penelitian ini adalah metode survei dengan pendekatan kuantitatif. Penelitian survei yang dimaksud adalah bersifat menjelaskan hubungan kausal dan pengujian hipotesis. Studi yang dikembangkan dalam penelitian ini dilakukan dengan studi kepustakaan dan studi lapangan.

Populasi dalam penelitian ini adalah semua guru ilmu Bahasa Arab di Madrasah Tsanawiyah Pesantren di kota Lhokseumawe yang berjumlah 11 MTsS pesantren, jumlah guru bahasa Arab sebanyak 27 orang, peneliti akan mengambil sampel dari seluruh total populasi, karena makin tinggi jumlah sampel maka akan semakin representative. Dengan demikian jumlah sampel adalah 27 orang.

Data penelitian dikumpulkan dengan menggunakan kuesioner/angket dengan skala Likert.Kuesioner yang diberikan telah melalui tahap uji validitas dan reliabilitas. Tehnik analisis yang digunakan untuk menganalisis data statistik parametik dengan menggunakan analisis regresi linear sederhana. 


\section{Hasil dan Pembahasan}

\section{Hasil Penelitian}

\section{1). Variabel Kepemimpinan Kepala Sekolah (X)}

Pada pembahasan ini akan mengukur sejauh mana respon yang diberikan guru terhadap gaya kepemimpinan yang diberikan oleh Kepala Sekolah, dalam hal ini indikator kepemimpinan terdiri dari 2 aspek dengan 12 indikator. Data tentang kepemimpinan Kepala Sekolah MTsS Pesantren di Kota Lhokseumawe menunjukkan bahwa total skor tertinggi adalah 119 dan total skor terendah adalah 61. Hasil analisis disajikan dalam bentuk tabel sebagai berikut:

Tabel 1. Distibusi Frekuensi Orientasi Kepemimpinan Kepala Sekolah

\begin{tabular}{|c|c|c|c|c|}
\hline No & Kategori & Interval & $\begin{array}{c}\text { Jumlah } \\
\text { Responden }\end{array}$ & Persentase \\
\hline 1 & Sangat tinggi & $X \geq 119$ & 1 & 4 \\
\hline 2 & Tinggi & $119>X \geq 73$ & 22 & 81 \\
\hline 3 & Rendah & $73>X \geq 27$ & 4 & 15 \\
\hline 4 & Sangat rendah & $X<27$ & 0 & 0 \\
\hline & \multicolumn{2}{|c|}{ Total } & 27 & 100 \\
\hline
\end{tabular}

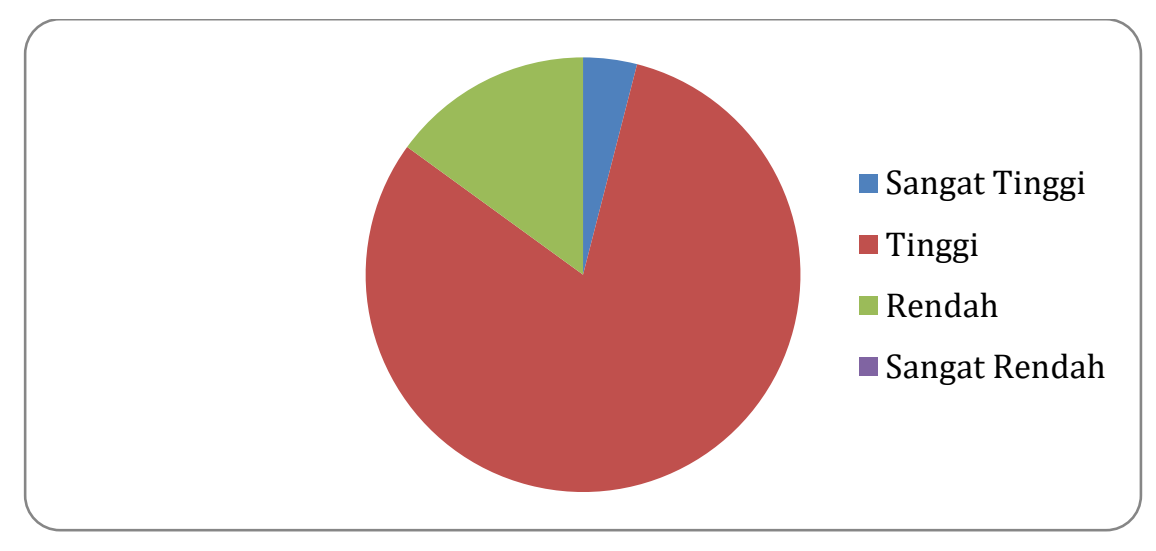

Gambar 1. Diagram Persentase Kepemimpinan Kepala Sekolah 
Berdasarkan tabel dan diagram di atas diketahui bahwa kepemimpinan kepala sekolah MTsSS Pesantren di Kota Lhokseumawe dalam melaksanakan tugasnya terlihat (1) kategori sangat rendah tidak ada $0 \%$, (2) kategori rendah sebanyak 4 guru atau $15 \%$, (3) kategori tinggi sebanyak 22 guru atau 81\%, dan (4) kategori sangat tinggi sebanyak 1 guru atau 4\%. Jadi dapat diketahui bahwa kepemimpinan kepala sekolah dalam hal pelaksanaan tugas dan membangun hubungan yang baik (human relation) termasuk dalam kategori tinggi, hal ini ini ditandai dengan persentase $81 \%$ atau 22 guru memberikan persetujuannya.

\section{2). Variabel Profesionalisme Guru Bahasa Arab (Y)}

Selanjutnya pembahasan ini akan mengukur sejauh mana profesionalisme guru Bahasa Arab dalam proses pembelajaran, dari 9 indikator profesionalisme tersusun tersusun 12 pernyataan dengan skor 1-5 dari setiap pernyataan. Data tentang profesionalisme guru Bahasa Arab dari 27 responden guru bahasa Arab MTsSS Pesantren di Kota Lhokseumawe menunjukkan bahwa total skor tertinggi adalah 47 dan total skor terendah adalah 25. Hasil analisis disajikan dalam tabel sebagai berikut:

Tabel 2. Distibusi Frekuensi Orientasi Profesionalisme Guru Bahasa Arab

\begin{tabular}{|c|c|c|c|c|}
\hline No & Kategori & Interval & $\begin{array}{c}\text { Jumlah } \\
\text { Responden }\end{array}$ & Persentase \\
\hline 1 & Sangat tinggi & $X \geq 47$ & 5 & 19 \\
\hline 2 & Tinggi & $47>X \geq 36$ & 19 & 70 \\
\hline 3 & Rendah & $36>X \geq 25$ & 3 & 11 \\
\hline 4 & Sangat rendah & $X<25$ & 0 & 0 \\
\hline & \multicolumn{2}{|c|}{ Total } & 27 & $100 \%$ \\
\hline
\end{tabular}




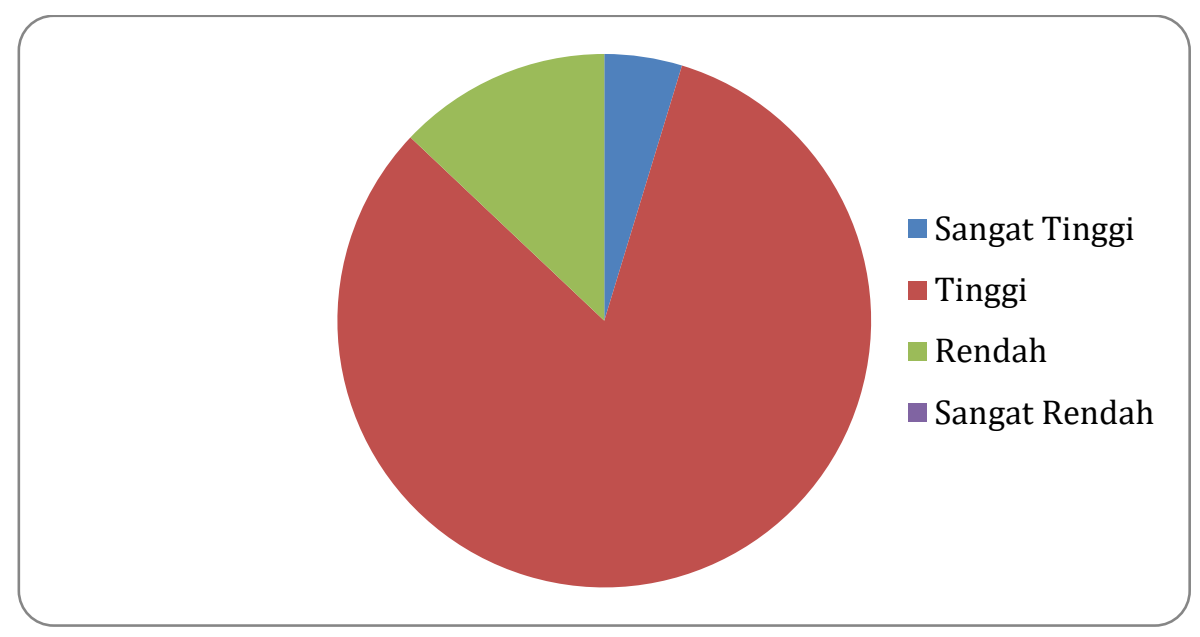

Gambar 2. Diagram Persentase Profesionalisme Guru Bahasa Arab

Berdasarkan tabel dan diagram di atas diketahui bahwa profesionalisme guru bahasa arab MTsS Pesantren di Kota Lhokseumawe dalam melaksanakan tugasnya terlihat (1) kategori sangat rendah tidak ada $0 \%$, (2) kategori rendah sebanyak 3 guru atau $11 \%$, (3) kategori tinggi sebanyak 19 guru atau 70\%, dan (4) kategori sangat tinggi sebanyak 5 guru atau 19 \%. Jadi dapat diketahui bahwa profesionalisme guru bahasa arab dalam mengembangkan kompetensi yang dimiliki secara profesional termasuk dalam kategori tinggi, hal ini ini ditandai dengan persentase $70 \%$ atau 19 guru memberikan persetujuannya.

\section{a. Pengujian Hipotesis}

Dalam penelitian ini menggunakan analisis regresi linear sederhana untuk mengetahui pengaruh variabel independent terhadap variabel dependent, yaitu variabel kepemimpinan kepala sekolah sebagai variabel bebas terhadap variabel profesionalisme guru Bahasa Arab sebagai variabel terikat. Berikut analisis menggunakan bantuan program komputer SPSS 17. 


\section{Hasil Uji Regresi Linear Sederhana}

Analisis regresi sederhana bertujuan untuk mengetahui ada atau tidaknya pengaruh variabel bebas $(\mathrm{X})$ terhadap variabel terikat $(\mathrm{Y})$ dan seberapa besar pengaruhnya variabel bebas (X) terhadap variabel terikat (Y).Koefisien regresi tersebut membentuk suatu persamaan sebagai berikut:

$$
\mathrm{Y}=\mathrm{a}+\mathrm{bX}=1,672+0.362 \mathrm{X}
$$

\section{1) a : 1,672}

Nilai konstan ini menunjukkan bahwa jika tidak ada variabel (X) yaitu kepemimpinan kepala sekolah maka nilai konsisten profesionalisme guru Bahasa Arab (Y) sebesar 1,672.

\section{2) b : 0.362}

Koefesien regresi variabel kepemimpinan kepala sekolah(X) adalah sebesar 0,362. Artinya jika variabel X nilainya tetap dan meningkat, maka profesionalisme guru Bahasa Arab juga akan meningkat sebesar 0,362 atau $36 \%$.

\section{Uji Determinasi $\left(R^{2}\right)$}

Sebelum dilakukan pengujian hipotesis terlebih dahulu dilakukan analisis korelasi. Hal ini untuk mengetahui seberapa besar hubungan variabel X (kepemimpinann) terhadap variabel Y (profesionalisme guru Bahasa Arab) serta banyaknya persentase tingkat konstribusi antar variabel independent (kepemimpinan Kepala Sekolah) terhadap variabel dependent (profesionalisme guru Bahasa Arab). Berikut adalah hasil pengujian dengan SPSS 17. 
Tabel 3 Uji Determinasi

Model Summary

\begin{tabular}{|c|c|c|c|c|}
\hline & & & $\begin{array}{c}\text { Adjusted } \\
\text { Model }\end{array}$ & $\begin{array}{c}\text { Std. Error of the } \\
\text { Rstimate }\end{array}$ \\
\hline 1 & $.881^{\mathrm{a}}$ & .776 & .767 & 3.60216 \\
\hline
\end{tabular}

a. Predictors: (Constant), Kepemimpinan Kepala

Sekolah

Berdasarkan tabel di atas dapat diketahui bahwa nilai koefisien determinasinya adalah 0,881 atau 88\%. Dapat dinyatakan bahwa ada korelasi atau hubungan antara variabel dependent (profesionalisme guru Bahasa Arab) dengan variabel independent (Kepemimpinan Kepala Sekolah) adalah baik. Jadi dapat di jelaskan bahwa profesionalisme guru Bahasa Arab dapat dijelaskan oleh kepemimpinan kepala sekolah sebesar $88 \%$ dan sisanya sebesar 12\% dijelaskan oleh variabel-variabel lain di luar persamaan.

\section{Uji Hipotesis}

Terdapat satu uji hipotesis dalam penelitian ini meliputi uji t. Dengan menggunakan analisis regresi linear sederhana yang berfungsi untuk mengetahui pengaruh secara parsial antara variabel bebas yaitu kepemimpinan kepala sekolah terhadap variabel terikat berupa profesionalisme guru Bahasa Arab, peneliti merumuskan hipotesis penelitian sebagai berikut:

Ha : Terdapat pengaruh yang positif dan signifikan gaya kepemimpinan kepala sekolah terhadap profesionalisme guru bahasa Arab MTsS pesantren di kota Lhokseumawe.

Ho : Tidak terdapat pengaruh yang positif dan signifikan gaya kepemimpinan kepala sekolah terhadap profesionalisme guru bahasa Arab MTsS pesantren di kota Lhokseumawe. 
Setelah pengujian diketahui nilai Signifikansi untuk pengaruh $\mathrm{X}$ terhadap $\mathrm{Y}$ adalah sebesar 0,00>0,05 dan nilai $t$ tabel $=\mathrm{t}(\alpha / 2 ; \mathrm{n}-1)=\mathrm{t}$ $(0,025 ; 26)=2,055$. Berarti nilai thitung lebih besar dari ttabel yaitu 9,308 > 2,055, maka $\mathrm{H}_{0}$ ditolak dan $\mathrm{H}_{a}$ diterima. Dengan demikian terdapat pengaruh positif signifikan kepemimpinan kepala sekolah terhadap profesionalisme guru Bahasa Arab MTsSS Pesantren di Kota Lhokseumawe.

\section{Pembahasan}

\section{1). Kepemimpinan Kepala Sekolah}

Hasil analisis data tentang kepemimpinan kepala sekolah didapatkan bahwa terdapat 22 guru (81\%) yang menyenangi gaya kepemimpinan kepala sekolah dan memiliki hubungan baik dengan kepemimpinan kepala sekolah. Hanya 4 guru (15\%) yang kurang menyenangi gaya kepemimpinan kepala sekolah. Dari hasil analisis data terlihat mayoritas kepala sekolah MTsSS pesantren di kota Lhokseumawe memiliki gaya kepemimpinan yang baik.

Hal ini sesuai denganperilaku kepemimpinan yang dikemukakan oleh Wahjosumidjo (1987, 61-62) yang harus memiliki sikap yang baik terhadap bawahan yaitu (a) ramah tamah, (b) mendukung dan membela bawahan, (c) mau mendengar bawahan, (d) menerima usul bawahan, (e) memikirkan kesejahteraan bawahan, (f) memperlakukan bawahan setingkat dirinya, sedangkan struktur inisisasi adalah perilaku pemimpin yang cenderung lebih mementingkan tujuan organisasi dari pada mementingkan bawahan. Kepemimpinan merupakan salah satu faktor yang sangat penting dalam suatu organisasi karena sebagian besar keberhasilan dan kegagalan suatu organisasi ditentukan oleh kepemimpinan dalam organisasi tersebut. 


\section{2). Profesionalisme Guru Bahasa Arab.}

Dari hasil analisis data tentang tingkat profesionalisme guru bahasa Arab MTsSS Pesantren di Kota Lhokseumawe didapatkan bahwa 70\% (19 guru) sudah mampu mengembangkan kompetensinya untuk menjadi guru profesional dan hanya 11\% (3 guru) yang termasuk kategori rendah atau belum mampu mengembangkan kompetensinya untuk menjadi guru profesional terutama dalam proses pembelajaran bahasa arab. Untuk menjadi guru yang berkualitas tentunya para guru khususnya guru bahasa arab harus memahami hak dan kewajibannya sebagai pendidik, serta mampu bertanggung jawab dalam mengembangkan kualitas sumber daya manusia yang lebih baik.

Untuk mengembangkan kompetensi guru agar dapat menjadi guru ynag profesional, seorang guru harus memahami tanggung jawab utamanya sebagai pendidik dan memahami kriteria untuk menjadi guru yang profesional. Seperti yang dikemukakan oleh Ani M. Hasan (2004) menjelaskan bahwa guru yang profesional harus memenuhi kriteria, diantaranya: (1) mempunyai komitmen terhadap siswa dan proses belajarnya, (2) menguasai secara mendalam bahan atau mata pelajaran yang diajarkannya serta cara mengajarnya kepada siswa, (3) bertanggungjawab memantau hasil belajar siswa melalui berbagai cara evaluasi, (4) mampu berpikir sistematis tentang apa yang dilakukannya dan belajar dari lingkungan profesinya.

\section{3) Pengaruh Kepemimpinan Kepala Sekolah Terhadap Profesionalisme Guru Bahasa Arab}

Hasil analisis data tentang pengaruh kepemimpinankepala sekolah terhadap profesionalisme guru bahasa arab MTsS Pesantren di Kota Lhokseumawe yang telah di uji -t didapatkan nilai signifikansi yaitu 9,308 $>2,055$, sehingga dapat disimpulkan bahwa Ha diterima dan Ho ditolak. Hal ini menunjukkan bahwa terdapat pengaruh variabel 
X (kepemimpinan kepala sekolah) terhadap variabel Y (profesionalisme guru bahasa arab). Dengan demikian terdapat pengaruh positif signifikan kepemimpinan kepala sekolah terhadap profesionalisme guru bahasa arab, artinya dengan adanya kepemimpinan yang berorientasi pada tugas dan hubungan yang baik (human relation) berpengaruh positif terhadap profesionalisme guru dalam menjalankan tugasnya di sekolah.

Dari hasil analisis data ditemukan bahwa kinerja kepala sekolah MTsS Pesantren di Kota Lhokseumawe sudah baik, mayoritas kepala sekolah sudah memahami tugas manajerialnya dalam mengelola sekolah dan mengarahkan guru khususnya guru bahasa arab untuk dapat meningkatkan kompetensi yang dimilikinya. Tentunya hal ini sejalan dengan yang dikemukakan oleh Wahjosumidjo (2005) dimana Kepala sekolah adalah seorang tenaga fungsional guru yang diberi tugas tambahan untuk memimpin suatu sekolah di mana diselenggarakan proses belajar mengajar. Dalam menjalankan tugas dan fungsi kepemimpinan kepala sekolah harus mempunyai kemampuan untuk menggerakkan, mengerahkan, membimbing, melindungi, membina, memberi teladan, memberi dorongan, dan memberi bantuan terhadap semua sumber daya manusia yang ada di suatu sekolah sehingga dapat didayagunakan secara maksimal untuk mencapai tujuan yang telah ditetapkan.

Peningkatan kompetensi guru khususnya guru bahasa arab untuk menjadi guru profesional salah satunya dapat didukung oleh gaya kepemimpinan kepala sekolah dalam melaksanakan tugasnya, hal ini dapat dilakukan dengan adanya pengontrolan dan adanya sistem evaluasi kinerja guru serta adanya penghargaan terhadap kinerja guru yang baik. Dalam penelitian ini terlihat bahwa mayoritas guru bahasa arab di Kota Lhokseumawe menilai kepemimpinan kepala sekolah baik termasuk kategori tinggi, dimana adanya dukungan yang baik bagi guru 
dalam meningkatkan kualitasnya, adanya keterlibatan guru dalam mengambil keputusan terkait kemajuan MTsS Pesantren di Kota Lhokseumawe. Tingkat profesionalisme guru bahasa arab MTsS pesantren di Kota Lhokseumawe tidak hanya terkait dengan kepemimpinan kepala sekolah, namun ada faktor lain terutama motivasi diri guru tersebut.

Jadi berdasarkan uraian di atas yang dimaksud kepemimpinan kepala sekolah dalam penelitian ini adalah pola perilaku kepala sekolah terkait tugas dan hubungan yang dibangun dalam melaksanakan tugasnya telah mampu meningkatkan kompetensi guru bahasa arab untuk menjadi guru profesional, dengan adanya pengontrolan dan dorongan bagi guru untuk aktif dalam melaksanakan kewajibannya sebagai pendidik. Adanya pemahaman kepala sekolah terhadap tugasnya, tentunya dapat membangun komunikasi yang baik serta hubungan kerjasama dengan guru khususnya guru bahasa arab. Sehingga akan mampu meningkatkan motivasi bagi guru untuk terus meningkatkan kompetensinya menjadi guru bahasa arab yang profesional.

\section{KESIMPULAN}

Berdasarkan hasil penelitian melalui analisis regresi sederhana maka peneliti dapat menyimpulkan bahwa tingkat kepemimpinan kepala sekolah berada di kategori tinggi sebesar $81 \%$ atau 22 responden menyukai dan menyenangi akan kepemimpinan kepala sekolah di Pesantren Kota Lhokseumawe. Hasil analisis data terhadap profesionalisme guru bahasa Arab didapatkan bahwa tingkat kepemimpinan kepala sekolah berada di kategori tinggi sebesar 70\% atau 19 guru bahasa Arab MTsS Pesantren di Kota Lhokseumawe telah mampu mengembangkan kompetensinya menjadi guru bahasa Arab yang profesional. Kemudian peneliti juga menguji hipotesis dan 
menyatakan bahwa terdapat pengaruh positif signifikan kepemimpinan kepala MTsS Pesantren di Kota Lhokseumawe terhadap profesionalisme guru bahasa arab dengan nilai signifikansi $0,00>0,05$ dimana nilai thitung lebih besar dari tabel yaitu 9,308 > 2,055 sehingga Ha diterima dan Ho ditolak.. Hal ini dapat diartikan bahwa kepemimpinan kepala sekolah baik aspek tugas maupun hubungan yang terjalin dengan guru berpengaruh positif terhadap profesionalisme guru bahasa Arab MTsS Pesantren di Kota Lhokseumawe.

Kepala sekolah agar dapat terus meningkatkan pemahamannya terkait tugas manajerialnya dan mampu membangun hubungan serta komunikasi yang baik dengan guru dan perangkat sekolah lainnya, sehingga kualitas para guru serta sekolah MTs baik negeri ataupun swasta Kota Lhokseumawe menjadi lebih baik dan berkualitas. Untuk dapat meningkatkan kualitas pendidikan menjadi lebih berkualitas dan mampu bersaing diera MEA saat ini maka diharapkan guru mampu mengembangkan kompetensinya menjadi guru yang profesional, terus berinovasi untuk menciptakan proses belajar mengajar yang aktif dan menyenangkan.

\section{DAFTAR PUSTAKA}

Dedi Supriadi dan Jalal, (2001), Reformasi Pendidikan Dalam Konteks Otonomi Daerah, Jakarta, Adicipta Karya Nusa.

Hasan, Ani M, (2004), Pengembangan Profesionalisme Guru. Surabaya: Seminar Nasional Pendidikan.

Miswari, (2010), Peningkatan Profesionalisme Guru Bahasa Arab: Upaya Peningkatan Mutu Pembelajaran Bahasa Arab, Jurnal Ta'dib, Vol. XV. No. 02. Edisi, Hal: 255-272.

Muhibbin Syah, 1999,Psikologi Pendidikan Dengan Pendekatan Baru, Bandung, PT Rosdakarya.

Mulyadi, (2010), Kepemimpinan Kepala Sekolah Dalam Mengembangkan Budaya Mutu, Malang, UIN Maliki Press. 
Riduwan, (2015),Metode \& Teknik Menyusun Proposal Penelitian, Bandung, Alfabeta.

Siagian Sondang P, (1996), Manajemen Sumber Daya Manusia, Jakarta, Bumi Aksara.

St. Kuraidah, (2013), Kinerja Supervisor dan Profesionalisme Guru Bahasa Arab Madrasah Aliyah di Kota Kendari, Jurnal Al-Izzah, Vol. 8 No. 2, Hal: 104-123.

Sutarto, (2011), Dasar-Dasar Kepemimpinan Administrasi, Yogyakarta, Gajah Mada University Press.

Wahjosumidjo, (1987), Kepemimpinan dan motivasi, Jakarta, Ghalia Indonesia.

Wahjosumidjo. (2005), Kepemimpinan Kepala Sekolah, Tinjauan Teoritik dan Permasalahannya, Jakarta; Raja Grafindo Persada.

Undang-undang RI. No.14 Tahun 2005 dan PP No.19 Tahun 2005. 